\title{
再生細骨材を用いたモルタルの細孔構造 の粗大化と強度及び耐久性の低下
}

\author{
松下博通 1 ・佐川康貴 2 ・川端雄一郎3 \\ 1フェロー会員九州大学大学院＼cjkstart教授＼cjkstart建設デザイン部門（†812-8581福岡市東区箱崎6-10-1） \\ E-mail:matsu@doc.kyushu-u.ac.jp \\ 2正会員 九州大学大学院 助手 建設デザイン部門（同上） \\ 3学生会員 九州大学大学院 工学府 建設システム工学専攻 (同上)
}

\begin{abstract}
本研究は再生細骨材を使用したモルタルの強度及び而久性の低下機構について細孔構造の観点から考察 したものである。再生細骨材を使用したモルタルはセメントペースト部の細孔構造がポーラスになり, 強 度や耐久性が低下寸る。これは骨材から水分が滲出することが原因と考えられる。特に50nm〜2 $\mu \mathrm{m}$ の細孔 容積と強度や中性化速度係数及び塩化物イオンの見かけの拡散係数に良い相関関係が確認できる。また， 強度及び而久性の改善を目的として各種混和材を混入した。 その結果, 混和材を混入することにより再生 モルタルの強度及び塩分浸透抵抗性が改善されることを明らかにした．また，混和材を混入することによ り中性化抵抗性は低下寸るが，本研究において予測式を提案し，それにより対応可能であることを示した。
\end{abstract}

Key Words : recycled aggregate, porosity, strength, durability, mineral admixtures

\section{1.はじめに}

近年における我が国の自然環境保全意識は非常に 高い. 平成 12 年に循環型社会形成推進基本法が制 定され，リサイクルに関する動向は活発化している 特に産業廃棄物のうち $40 \%$ 強もの排出量であるコン クリート塊の再生骨材としての有効利用は必要不可 欠である、また，これまで我が国のコンクリート用 骨材は海砂や砕石等に大きく依存してきた。しかし， 海砂の採取は全面禁止の方向に進みつつあり, コン クリート用細骨材の供給不足が懸念されている.こ のことから, 海砂代替骨材の開発は急務であり, そ のひとつとして再生骨材が着目されている.

このような状況を鑑夕，再生骨材に関する各方面 における研究や, 建設副産物情報交換システムの開 発も盛んに行われている。 これまで種々の高度な再 生骨材の処理方法の開発や工法が提案されてきてい る ${ }^{1), 2)}$. また, 平成 16 年に標準仕様書 TS A 0006 「再生骨材を用いたコンクリート」が開示され，再生 コンクリートを使用する上での基準化及び標準化も 活発化している.

しかし，これらの対策が再生骨材の有效利用を促 す上で必ずしも有効なものとは言い難い. 高品質な
再生骨材を製造するためには，コストの増加や製造 の際の微粉の発生等の問題がある。これらは, LCA の観点からも必ずしも優位とはいえない。また, TS A 0006 では再生コンクリートの用途範囲として, 高 い品質を要求されない構造物あるいは部位に限定し ており，呼び強度の上限は 18 と設定している。し かし，1970 年代の高度経済成長期に製造された大量 のコンクリート構造物が今後寿命を迎え, コンクリ 一ト塊の発生量が加速度的に増大寸ることが予想さ れることから, 再生骨材の用途範囲の拡大を検討す る必要がある。つまり, 高品質な再生骨材でなく, 低品質な再生骨材であっても適材適所に有効利用し, その要求性能に応じた改善方法を考慮す心゙きである.

筆者らは低品質な再生骨材を用いたコンクリート の鉄筋コンクリート構造物への適用を視野に入れて いる。 そのためには再生コンクリートの強度及び而 久性の改善が必須である.

そこで，本研究は再生骨材を用いたコンクリート に関する既往の研究をまとめ, それらを基に再生骨 材の含有する水による強度低下メカニズムを推測し た.また，そのメカニズムを踏まえた改善方法とし て混和材を混入することを提案し, その改善効果に ついて検討を行った。 


\section{2. 既往の研究}

本章においては，再生コンクリートの硬化性状に おける既往の研究及び品質改善に関する既往の研究 をまとめる。また, それらから得られる情報から既 往の研究の問題点及び今後の課題を抽出するととも に，本研究の位置付けを明確にする.

\section{（1）再生コンクリートの強度及び耐久性}

再生骨材の品質や再生コンクリートの配合が再生 コンクリートの圧縮強度に及ぼす影響については, 数多くのデータが蓄積されつつある ${ }^{3)}$. 一般的に再 生コンクリートの強度は低下し, その低下度は再生 細骨材の使用による影響が大きい(4),5),6)。しかし，低 品質な再生粗骨材を使用した場合は，再生コンクリ 一トの強度は再生細骨材による影響よりも大きいと の指摘もある ${ }^{7)}$. また, 再生骨材はポンプ圧送性や スランプロスの観点からプレウェッティングするこ とが望ましく, 骨材の吸水率による強度低下が眯念 される. この問題を解決するため, 麓らは骨材の吸 水率を考慮したセメント総水量比 $C / T W($ 式(1))によ り圧縮強度を推定している ${ }^{8)}$.

$$
C / T W=\frac{C}{W+W_{s}}
$$

ここに，

$C$ :単位体積あたりのセメントの質量 $\left(\mathrm{kg} / \mathrm{m}^{3}\right)$

$T W$ :単位体積あたりの総水量 $\left(\mathrm{kg} / \mathrm{m}^{3}\right)$

$W$ :単位体積あたりの水の質量 $\left(\mathrm{kg} / \mathrm{m}^{3}\right)$

$W_{s}$ :単位体積あたりの細骨材の吸水量 $\left(\mathrm{kg} / \mathrm{m}^{3}\right)$

また, 再生コンクリートの強度低下メカニズムと して骨材に吸収された水がセメントペースト部に移 動し，コンクリートの細孔径分布に影響を及ぼした としている.

長瀧ら ${ }^{9)}$ は，原コンクリートの強度が高い場合で あれば高強度の再生コンクリートを作製可能である が，低い場合には限界があることを示している。大 即ら ${ }^{10)}$ は旧境界相である付着モルタルのビッカース 硬さが新境界相である新モルタル部のビッカース硬 さより大きい場合，コンクリートの強度は骨材の種 類や品質の影響を受けないと報告している. Poon $5^{11)}$ は再生骨材自身の細孔容積を測定し, 再生骨材 の細孔容積が普通骨材と比較して多く，その量は原 コンクリートによって異なることを示している。ま た，SEM 観察により再生コンクリートの骨材界面 はポーラスになっており，これは再生骨材の空隙と 吸水率によるものであると考察している。
再生コンクリートの中性化及び塩分浸透抵抗性に 関する文献は少ない。筆者ら ${ }^{12)}$ は再生コンクリート の中性化及び塩分浸透性状について検討した結果, 再生細骨材の影響が大きいことを明らかにしている。 また, 中性化性状に関して, 麓・山田 ${ }^{8)}$ は $C / T W$ と 中性化深さの相関関係が高いことを明らかにしてい る. 中本ら ${ }^{13)}$ は処理方法を変化させた再生骨材を用 いたコンクリートの中性化について検討し, 処理回 数の最も少ない再生骨材の組み合わせが最も中性化 速度が大きいということを明らかにしている。

\section{(2) 再生コンクリートの品質改善}

宮本ら ${ }^{14)}$ はシリカフュームスラリーに再生骨材を 浸漬させ，再生骨材の強度改善を図った。その結果， 再生骨材自身の強度には若干の改善効果が見られた が，コンクリートの圧縮強度の改善効果はほとんど 得られなかったことを明らかにしている。また，辻 ら ${ }^{15)}$ はコロイダルシリカ溶液に再生骨材を浸漬させ ることにより再生骨材の品質が改善され, 再生コン クリートの品質が向上することを明らかにしている。 大即ら ${ }^{10)}$ はダブルミキシング工法により骨材界面 の改善を図り， $W / C=55 \%$ であっても強度や物質透過 性の改善が可能であることを明らかにしている。ま た，黒田ら ${ }^{16)}$ は，加熱すりもみ処理を行うことによ り高品質再生骨材を作製し，普通コンクリートとほ ぼ同等の性状を確保することが可能であることを明 らかにしている。今本ら ${ }^{17)}$ は練混ぜ時に減圧処理を 行うことにより，骨材とペーストを圧着させるため， 強度の改善が可能であることを示している.

\section{(3) 本研究の位置付け}

再生コンクリートの強度及び而久性はセメント総 水量比 $C / T W$ にって一義的に表現可能であるとさ れているが，その原因については十分には明確にな っていない。また, 長瀧ら, 大即らの報告から, 再 生コンクリートにおいては $C / W$ あるしきい值から 強度には限界があると考えられ，C/TWのみでは十 分な評価が行えない可能性がある.

一般的に，普通強度レベルのコンクリートの強度 は骨材とセメントペーストの界面部分に存在する遷 移帯に依存する。遷移帯は, 粗大な空隙に富む不連 続な領域であり，強度や物質透過性といったコンク リートの品質に大きく影響を与える ${ }^{18), 19), 20)}$. 再生コ ンクリートの強度・耐久性もセメントペースト部の 細孔構造に大きな影響を受けるものと考えられる。

また，これまでの再生コンクリートの品質改善に 関する研究は, 再生骨材自身の強度を改善する工法 
等が多いが，十分な強度改善効果は得られていない。 また，大即らの報告から，界面性状を改善すること により強度及び物質透過性の改善が可能であること が明らかになっていることから，コンクリートの空 隙量の低減が最も有効であると考えられる.

本研究は，低コストで可能な再生コンクリートの 品質改善方法について主眼を置いている.よって, 本研究はまず細孔構造の観点から再生細骨材を使用 したモルタルの強度及び而久性の低下機構について 検討した.

次に，高炉スラグ微粉末やフライアッシュといっ た混和材の混入により再生モルタルの細孔構造の緻 密化を図り, その効果について検討を行った.

\section{3. 実験概要}

本研究は, 細孔構造と強度及び而久性, また各種 混和材による品質改善効果について検討するため, 以下の要領で実験を行った。

\section{(1) 再生骨材}

本研究で使用した再生骨材は材齢 6 ケ月の PC 版 をブレーカで $250 \mathrm{~mm}$ 程度に粗砕後, インパクトク ラッシャを 1 回通過させ， $5 \mathrm{~mm}$ ふるるい通過したも の全量を試料とした。 原コンクリートの示方配合を 表-1 に示す。原コンクリートは目標スランプ $6.5 \pm 1.5 \mathrm{~cm}$, 目標空気量 $4.5 \pm 1.5 \%$ であり, 原コンク リートから採取したコア供試体 $(\phi 10 \times 20 \mathrm{~cm})$ より 再生骨材製造時における圧縮強度及び静弾性係数を 求めたところ, それぞれ $42.2 \mathrm{~N} / \mathrm{mm}^{2}, 30.5 \mathrm{kN} / \mathrm{mm}^{2}$ で あった。

本研究で使用した再生骨材の物理的性質を表-2 に示す．表中のペースト付着率は，約 5\%の塩酸に 再生細骨材を浸漬した後, 水洗いの際に $0.075 \mathrm{~mm}$ ふるいを通過したものの割合を表したものである. 本研究が使用した再生骨材の吸水率は TS A 0006 で は区分外と判定され, 低品質であることが分かる. また，使用した細骨材の粒度分布を図-1 に示す。 再生細骨材は粒度調整を行っておらず，粒度分布が TS A 0006 の粒度規格から大きく外れていることが 分かる.

\section{(2) 使用材料及びモルタルの配合}

モルタルの配合は, 水セメント比 $W / C=40,50$, $60 \%$, 砂セメント比 $S / C=3$ とした。再生骨材及び海 砂は表乾状態でそれぞれ使用した。 セメントは全て
表-1 原コンクリートの示方配合

\begin{tabular}{c|c|c|c|c|c}
\hline \multirow{2}{*}{$\mathrm{W} / \mathrm{C}$} & \multicolumn{6}{|c}{ 単位量 $\left(\mathrm{kg} / \mathrm{m}^{3}\right)$} \\
\cline { 2 - 6 } & $\begin{array}{c}\text { 水 } \\
\mathrm{W}\end{array}$ & $\begin{array}{c}\text { セメント } \\
\mathrm{C}\end{array}$ & $\begin{array}{c}\text { 細骨材 } \\
\mathrm{S}\end{array}$ & $\begin{array}{c}\text { 粗骨材 } \\
\mathrm{G}\end{array}$ & $\begin{array}{c}\text { 高性能AE } \\
\text { 減水剂 }\end{array}$ \\
\hline 40.7 & 171 & 420 & 674 & 1124 & 2.52 \\
\hline
\end{tabular}

表-2 細骨材の物理的性質

\begin{tabular}{ll|c|c}
\hline & & 再生細骨材 & 海砂 \\
\hline 絶乾密度 & $\left(\mathrm{g} / \mathrm{cm}^{3}\right)$ & 2.00 & 2.47 \\
\hline 吸水率 & $(\%)$ & 11.05 & 2.70 \\
\hline 実積率 & $(\%)$ & 69.9 & 66.4 \\
\hline ペースト付着率 & $(\%)$ & 37.7 & 0 \\
\hline
\end{tabular}

表-3 各種混和材の記号の種類

\begin{tabular}{c|c}
\hline 記号 & \multicolumn{1}{|c}{ 種類及び物理的性質 } \\
\hline FA-II & $\begin{array}{l}\text { フライアッシュII種 } \\
\left.\text { (密度 } 2.41 \mathrm{~g} / \mathrm{cm}^{3}, \text { 比表面積 } 4100 \mathrm{~cm}^{2} / \mathrm{g}\right)\end{array}$ \\
\hline FA-IV & $\begin{array}{l}\text { フライアシュIV種 } \\
\text { (密度 } 2.27 \mathrm{~g} / \mathrm{cm}^{3}, \text { 比表面積 } 2100 \mathrm{~cm}^{2} / \mathrm{g} \text { ) }\end{array}$ \\
\hline BFS & $\begin{array}{l}\text { 高炉スラグ微粉末 } \\
\text { (密度 } 2.90 \mathrm{~g} / \mathrm{cm}^{3}, \text { 比表面積 } 4180 \mathrm{~cm}^{2} / \mathrm{g} \text { ) }\end{array}$ \\
\hline
\end{tabular}

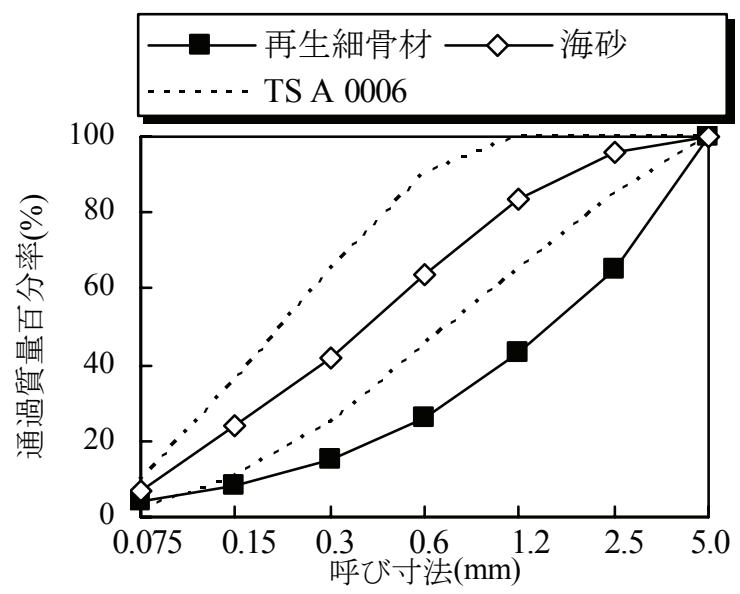

図-1 使用した細骨材の粒度分布

の要因に対して普通ポルトランドセメント(密度 $3.16 \mathrm{~g} / \mathrm{cm}^{3}$, 比表面積 $3240 \mathrm{~cm}^{2} / \mathrm{g}$ ) 使用した。また $W / C=50 \%$ で，フライアッシュII種(FA-IIシリーズ)を セメント質量に対して内割で $10 ， 20 ， 30 \%$ 混入した。 高炉スラグ微粉末(BFSシリーズ)はセメント質量に 対して内割で30，50，70\%混入した。 さらに，フラ イアッシュIV種(FA-IVシリーズ)は細骨材に対して5, 10\%体積置換した。表-3に混和材の記号とその物理 的性質を示している. 以後, 海砂を使用したモルタ ルを標準モルタル(Nシリーズ), 再生骨材を使用し たモルタルを再生モルタル(Rシリーズ)と称する.

\section{（3）供試体の作製及び養生}

圧縮強度及び曲げ強度試験用のモルタルは $4 \times 4 \times$ 
$16 \mathrm{~cm} の$ 角柱供試体を用いた。 また，促進中性化試験 及び塩水浸漬試験は $10 \times 10 \times 40 \mathrm{~cm}$ の角柱供試体を用 い，材齢28日まで水中養生を行った，その後，材齢 35 日まで温度 $20^{\circ} \mathrm{C}$, 湿度 $60 \%$ の恒温恒湿室に静置し た。また，その間に打設時側面の2面を除く4面をエ ポキシ樹脂で被覆し，試験に供した。

\section{(4) 試験項目及び試験方法}

\section{a）圧縮強度及び曲げ強度試験}

モルタルは所定の材齢（材齢 7，28，91日）まで 水中養生を行い，その後，JIS A 5201に準拠して曲 げ強度試験及び圧縮強度試験を行った。

\section{b）促進中性化試験}

環境条件は，JIS A 1153 に従い，温度 $20^{\circ} \mathrm{C}$, 湿度 $60 \%, \mathrm{CO}_{2}$ 濃度 $5 \%$ とした。試験は材齢35 日より行っ た.

\section{c）塩水浸漬試験}

試験環境は，土木学会「浸せきによるコンクリー ト中の塩化物イオンの見掛けの拡散係数試験方法 (案)」を参考にし, 温度 $20^{\circ} \mathrm{C}, \mathrm{NaCl}$ 濃度 $10 \%$ とした。 試験は材齢35日より行った。

\section{(5) 測定項目及び方法}

\section{a）中性化深さ}

供試体を $10 \times 10 \times 5 \mathrm{~cm}$ に割裂し，割裂面にフェノー ルフタレイン $1 \%$ エタノール溶液を噴霧し未着色の 部分の長さを 20 点測定した平均を中性化深さとした. b) 塩分浸透深さ

供試体を $10 \times 10 \times 5 \mathrm{~cm}$ に割裂し，割裂面に $0.1 \mathrm{~N}$ 硝酸 銀水溶液を噴霧し，白色となった部分の長さを 20 点 測定し, その平均を塩分浸透深さとした.

\section{c）塩化物イオン濃度}

塩分浸透深さを測定した供試体を塩分浸透方向の 表面から深さ方向に $1 \mathrm{~cm}$ の厚さにカットし, JIS A 1154 に準じて電位差滴定法により全塩化物イオン 濃度及び可溶性塩化物イオン濃度を測定した。なお， 高炉スラグ微粉末を混入したモルタルの可溶性塩化 物イオン濃度の測定に関しては硫化物イオンなどの 妨害イオンの影響を考慮して, 過酸化水素水 $(30 \%)$ を添加し， 5 分間煮沸処理を行った後に測定した ${ }^{21)}$.

\section{d） 細孔径分布及びそのデータ処理}

細孔径分布測定用のモルタル試料をコンクリート カッターで切断し，一辺の長さ $5 \mathrm{~mm}$ の立方体状の試 料片とし, 大量のアセトンにより水和を停止させた. 真空乾燥を行った後に，測定範囲6.6nm〜 $190 \mu \mathrm{m}$ の 水銀圧入式ポロシメータにより少なくとも一つの要 因に対して3度測定した。

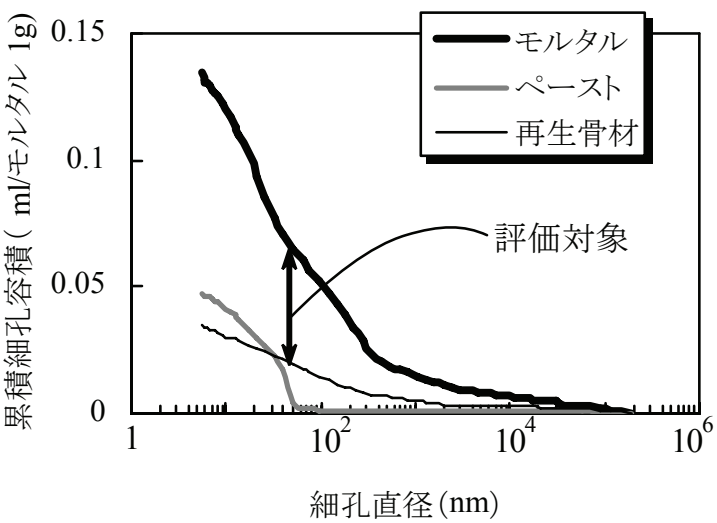

図-2 再生モルタルの細孔径分布 $(W / C=50 \%$ ，材齢 28 日 $)$

図-2に材龄28日における再生モルタルの細孔径分 布測定結果を示寸。なお，図中のペースト，再生骨 材はそれぞれ別途測定したものを $W / C=50 \%$ の再生モ ルタル中の質量割合に換算して示した．図より，ペ ーストでは50nm以上の径の細孔がほとんど存在し ないのに対し，モルタルには50nm以上の細孔径が 多く存在する。このような粗大な空隙は遷移帯に存 在し，モルタルの強度や物質透過性に大きく関与し ている ${ }^{22)}$ しかし，再生細骨材中の原骨材のみでな く付着ペーストにもそのような空隙が含まれる.

上述したように，一般的に圧縮強度や耐久性は遷 移帯の依存性が高いことから，再生骨材を使用した モルタル・コンクリートにおいても再生骨材に付着 する新ペースト部の細孔構造を把握することが重要 であると考えられる.Poonら ${ }^{11}$ は吸水率の高い再生 骨材を使用したコンクリートの骨材界面はポーラス になっていることをSEMにより観察し，これらが強 度や物質移動に支配的であるとしている。また，再 生細骨材の空隙量は再生モルタルの空隙量と比較し て比較的小さいことが分かる.

以上から, 本研究では再生細骨材中に含まれる細 孔容積を配合より求めた質量に換算したものを差し 引いた。この操作によってモルタル中における骨材 の細孔容積の影響を排除することができるため，再 生骨材に付着する新ペース卜部の細孔構造を間接的 に把握することができる．以後の細孔径分布の測定 結果は全てこのデータ処理を行っている.

\section{4. 再生モルタルの強度及び耐久性と細孔構造}

\section{(1) 再生モルタルの細孔構造}

図-3に材齢28日における各W/Cの標準モルタル及 び再生モルタルの細孔径分布測定結果を示す。図中 
のNは標準モルタルを, Rは再生モルタルを示して いる. 図より, 標準モルタル, 再生モルタルともに $W / C$ の増加に伴うペースト部の総細孔容積 $(6.6 \mathrm{~nm} \sim$ $190 \mu \mathrm{m})$ の増加が認められる.また, 再生モルタル中 のペースト部の総細孔容積は標準モルタルと比較し て大幅に大きくなった. セメントペースト部の空隙 分布は水セメント比の違いにより変化することから， 再生モルタルにおいてはモルタル内部でセメントペ 一スト部の水セメント比が増加していることを示唆 している。すなおち, 表乾状態で使用した再生細骨 材中に多量に含まれる水分が硬化中もしくは硬化後 にセメントペースト部に滲出し, 細孔構造をポーラ スにしたものと考えられる。本研究は, 既往の研究 を参考に, 再生モルタル中の新ペースト部の $50 \mathrm{~nm}$ 〜2 $\mu \mathrm{m} の$ 細孔容積について評価を行った.

図-4 に材齢に伴う $50 \mathrm{~nm} \sim 2 \mu \mathrm{m}$ の細孔容積の変化 を示す.アルファベットの後の数字は水セメント比 を表している。図より，材龄 7 日において既に再生 モルタル中のペースト部の細孔容積が大きいことか ら，モルタルの硬化時もしくは硬化後若材龄におい て骨材中の水分が滲出したものと考えられる. また, R40 は材齢 91 日において N50 とほぼ同等の細孔容 積となった。

骨材が含有する水分の移動現象について, 本研究 と同様の傾向が軽量骨材を用いたコンクリートにお いても報告されている ${ }^{22)}$. セメントペーストは水和 に伴って自己乾燥するため, 軽量骨材中の水分が相 対湿度の平衡を保つためにセメント硬化体中に移動 すると考えられており，本研究で使用した吸水率の 高い再生骨材においても同様の現象が生じたものと 推察される. この水分の挙動によって, セメント硬 化体の細孔構造が変化しているものと考えられる.

\section{(2) 再生モルタルの強度}

図-5は標準モルタル及び再生モルタルの $C / W$ と圧 縮強度の関係を示している.アルファベットの後の 值は材齢を示している. 各材齢において標準モルタ ル及び再生モルタルともに $C / W$ と圧縮強度には相関 関係が見られる。一般的に, 再生骨材を使用したコ ンクリートの強度低下原因として再生骨材中のひび 割れ等の影響が挙げられる。しかし, 図に示される ように再生モルタルの $C / W$ と強度の関係の傾きは標 準モルタルにおけるそれとほぼ同等であることから， 再生骨材を使用したモルタルの強度低下の原因には 再生骨材中のひび割れよりも上述したセメントペー スト部の細孔構造の粗大化の影響の方が卓越してい るものと考えられる. 図一6は麓らにより提案された

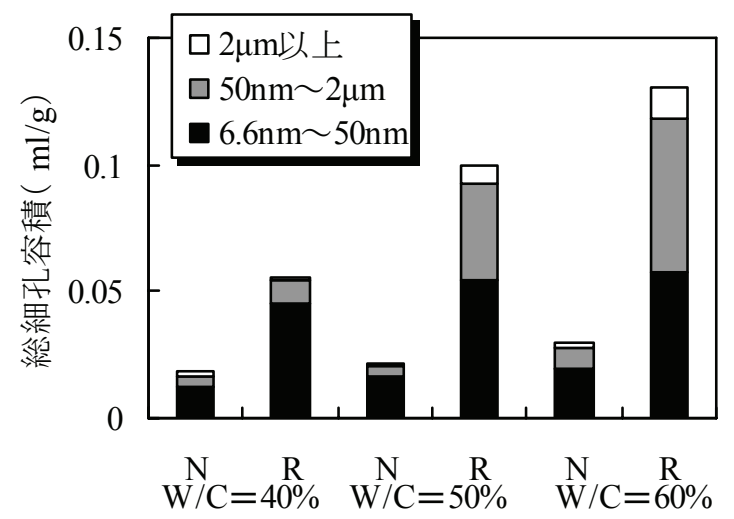

図-3 細孔容積測定結果(材齢 28 日)

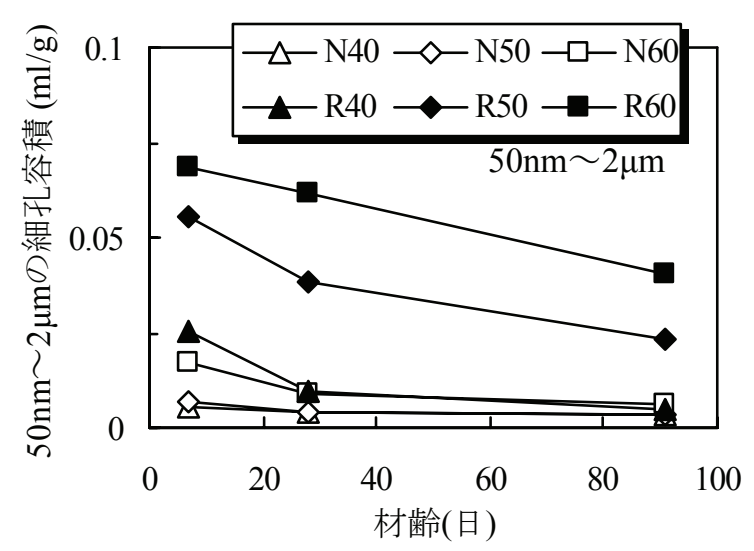

図-4 細孔容積の経時変化

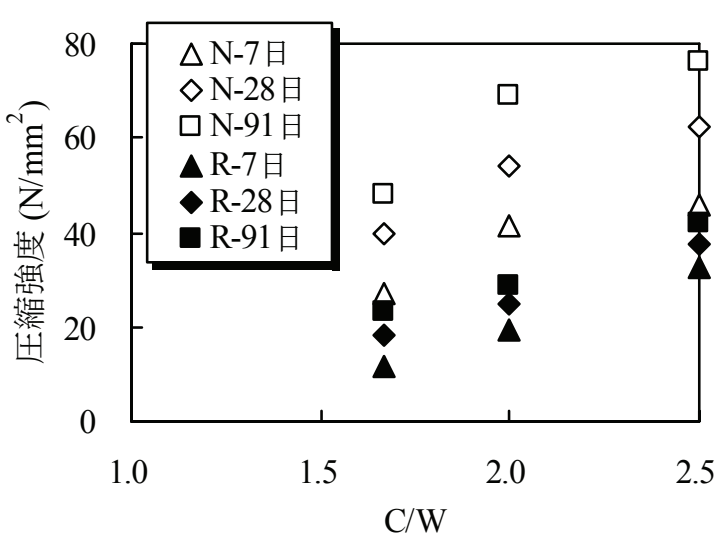

図-5 $C / W$ と圧縮強度の関係

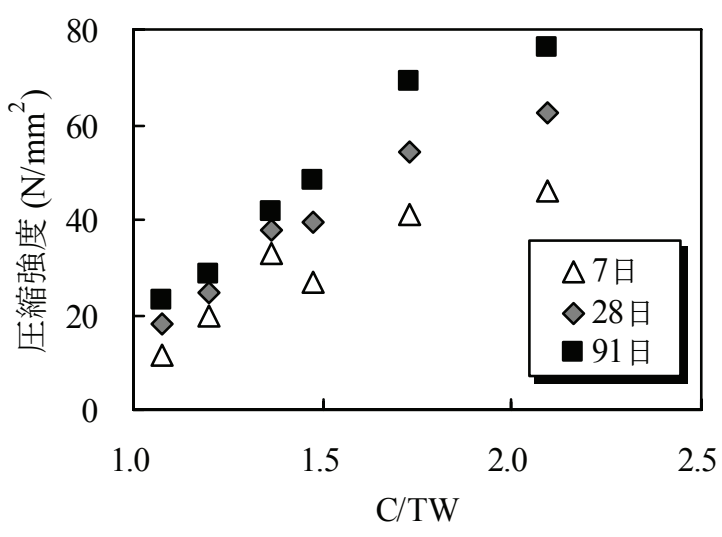

図-6 $\quad C / T W$ と圧縮強度の関係 
セメント総水量比 $C / T W^{10)}$ と圧縮強度の関係であるが, 再生骨材中の水分量を加味することにより良い相関 関係が得られることが分かる。このことは, 再生骨 材中の水分がセメントペースト部に沴出することを 裏付けているものと考えられる.

そこで，細孔径分布において最も強度に支配的で あるとされる遷移帯の空隙量に相当する $50 \mathrm{~nm}$ $2 \mu \mathrm{m}$ の細孔容積により評価を試みた ${ }^{23)}$. 図-7に $50 \mathrm{~nm} \sim 2 \mu \mathrm{m}$ の細孔容積の対数と圧縮強度の関係を 示す. 図より, $50 \mathrm{~nm} \sim 2 \mu \mathrm{m}$ の細孔容積の増加に従 い圧縮強度が低下していることが分かる。よって， 再生モルタル及び標準モルタルは粗大な空隙量の対 数により統一的に評価することが出来ると言える.

また，R40 は標準モルタルとほぼ同等の細孔容積 であるが，圧縮強度は低いことが分かる。この原因 については後述するが，再生骨材を使用したモルタ ルにおいてある程度低水セメント比とした場合には ある一定の強度において頭打ちとなる可能性がある。

\section{（3）再生モルタルの中性化性状}

図-8に再生モルタル及び標準モルタルの中性化深 さの経時変化を示す，再生モルタルは標準モルタル よりも中性化速度が速く，促進期間の平方根に従い 直線的に増加している。 よって，再生骨材を使用寸 ることにより中性化抵抗性が低下することが確認さ れた。また，R40の中性化深さはN60よりも小さい ことが分かる。図-9は $T W / C$ と中性化速度係数の関 係を示しているが，TW/C と中性化速度係数には相 関関係があり，既往の研究 ${ }^{8)}$ と一致した。なお，各 材齢において測定した中性化深さ20点のデータから 求めた標準偏差は約 $2 \mathrm{~mm}$ 以下であり, 再生骨材の使 用によるばらつきの程度の差は認められなかった。

再生骨材の中性化抵抗性低下の原因として, 上述 するように細孔構造の粗大化が挙げられる. 図-10 にそれぞれの要因のモルタルの材齢28日における $50 \mathrm{~nm} \sim 2 \mu \mathrm{m}$ の細孔容積の対数と中性化速度係数の関 係を示す。再生モルタル，標準モルタルともに $50 \mathrm{~nm} \sim 2 \mu \mathrm{m}$ の細孔容積が増加寸るに従い, 中性化速 度係数が大きくなるという傾向が分かる．以上から， 再生骨材を使用したモルタルの中性化抵抗性の低下 原因はセメントペースト部の細孔構造の粗大化であ ると言える。実用的には $T W / C$ にり中性化速度係 数を算定することが望ましいと考えられる.

\section{（4）再生モルタルの塩分浸透性状}

図-11に再生モルタル及び標準モルタルの塩分浸 透深さの経時変化を示寸，中性化と同様，再生モル

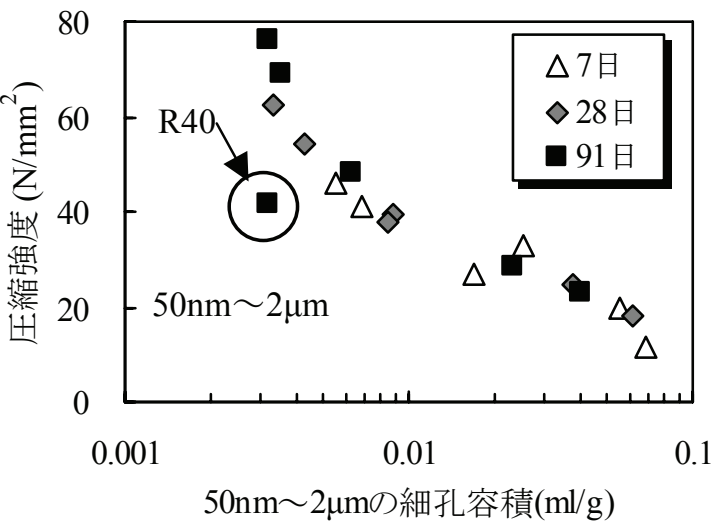

図-7 細孔容積と強度の関係

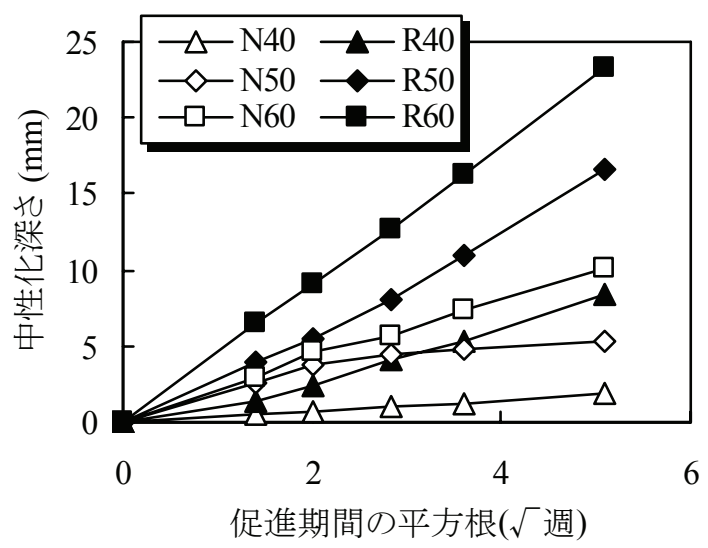

図-8 モルタルの中性化深さの経時変化

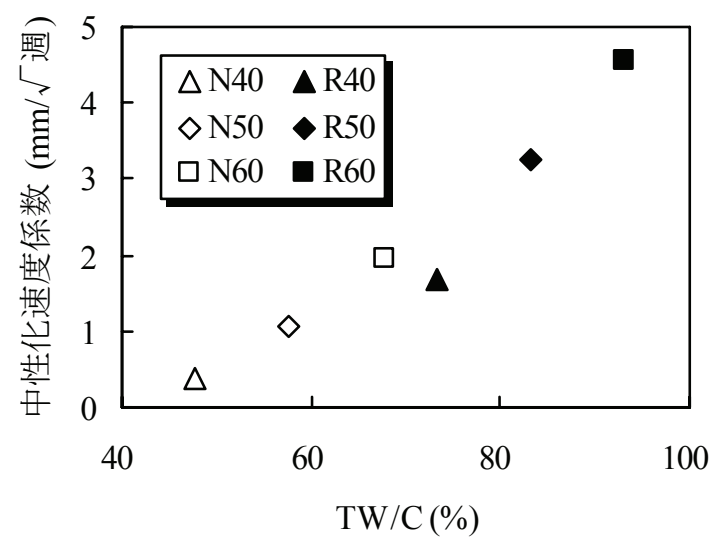

図-9 $T W / C$ と中性化速度係数の関係

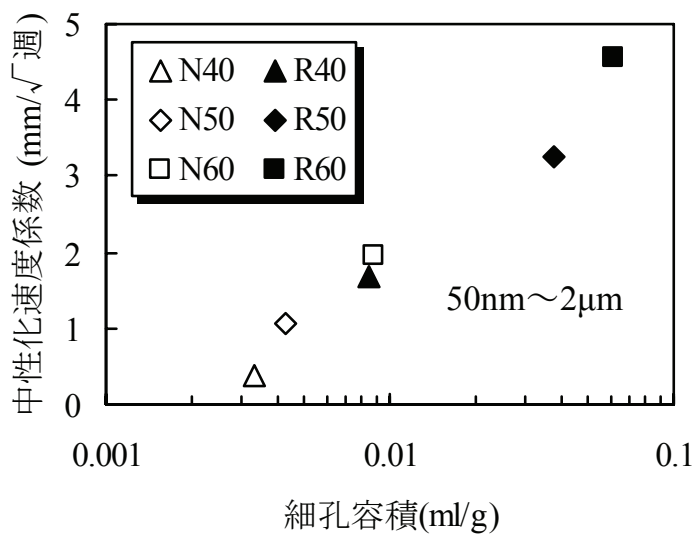

図-10 細孔容積と中性化速度係数の関係 
タルは標準モルタルよりも塩分浸透速度が速い。ま た，R40はN60よりも塩分浸透深さが小さくなって いる。N60とR40は細孔容積がほぼ同等であるが単 位セメント量が異なり， R40は塩化物イオンの固定 能がN50よりも高いためであると考えられる。なお， R60は試験材齢26週において塩分浸透深さが50mm以 上となり，測定不能であったため，詳細なデータを 明記していない。 なお塩分浸透深さについても，再 生骨材使用によるばらつきの差は認められなかった。

図-12は $T W / C$ と見かけの拡散係数の関係を示して いる。なお，見かけの拡散係数は最小二乗法により 全塩化物イオン濃度をFickの拡散方程式にフィッテ イングすることにより算出した。 $T W / C$ と見かけの 拡散係数には相関関係が見られ，塩化物イオンの拡 散も細孔構造の粗大化によって促進された可能性が 示唆される.

図-13はモルタルの材齢28日における50nm〜2 $2 \mu \mathrm{m}$ の細孔容積の対数と材齢 13 週における塩化物イオン の見かけの拡散係数の関係であり，細孔容積と見か けの拡散係数には良い相関が見られる。このことか ら，再生骨材を使用したモルタル・コンクリートの 塩分浸透抵抗性の低下原因はセメントペースト部の 細孔構造の粗大化であると考えられる.

図-14は再生モルタル及び標準モルタルの全塩化 物イオン濃度と可溶性塩化物イオン濃度の関係を示 している. 再生骨材を使用した際についても全塩化 物イオン濃度に対する可溶性塩化物イオン濃度の関 係は直線近似できるが，再生モルタルにおける全塩 化物イオン濃度に対する可溶性塩化物イオンの割合 は標準モルタルにおけるそれよりも大きくなった.

この原因として，セメントに同等の塩化物イオン固 定能がある場合でも再生モルタルの細孔量が標準モ ルタルと比較して多いため, 固相に対する液相の割 合が大きくなり，可溶性塩化物イオンが増加したこ とが考えられる。

\section{5. 細孔構造に着目した再生モルタルの強度 及び耐久性の改善方法}

前章において，再生骨材を使用したモルタルは再 生骨材から多量の水分がセメントペースト部へ滲出 することにより細孔構造がポーラスになり, 強度・ 耐久性が低下することを明らかにした。

そこで本研究は細孔構造の粗大化を改善するため に，各種混和材を混入することにより再生モルタル の強度及び耐久性の改善を図った。

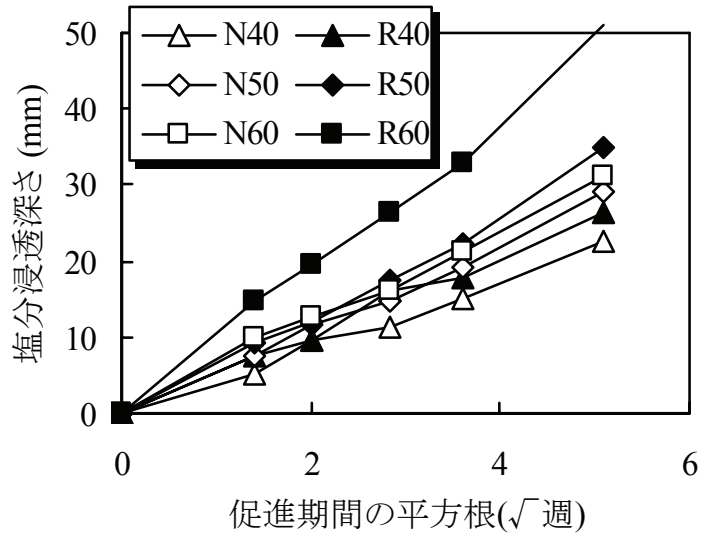

図-11 モルタルの塩分浸透深さの経時変化

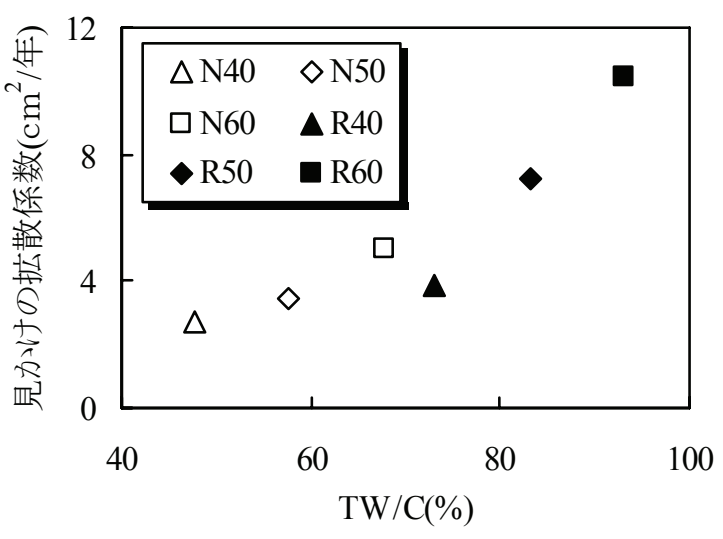

図-12 $T W / C$ と見かけの拡散係数の関係

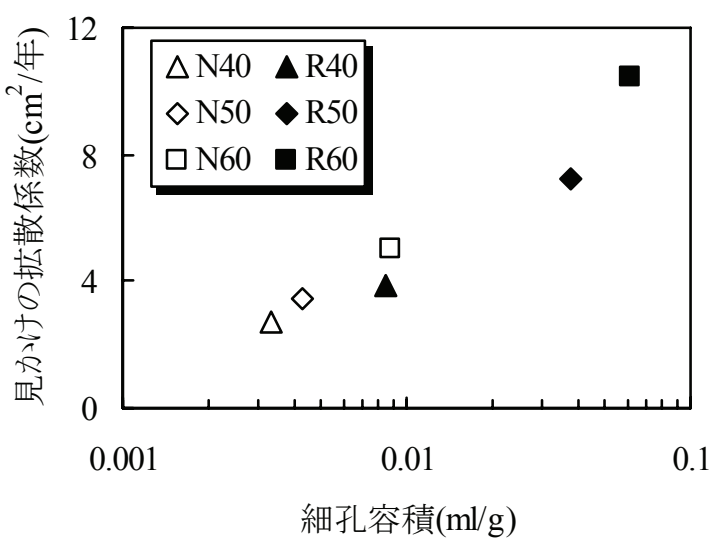

図-13 細孔容積と見かけの拡散係数の関係

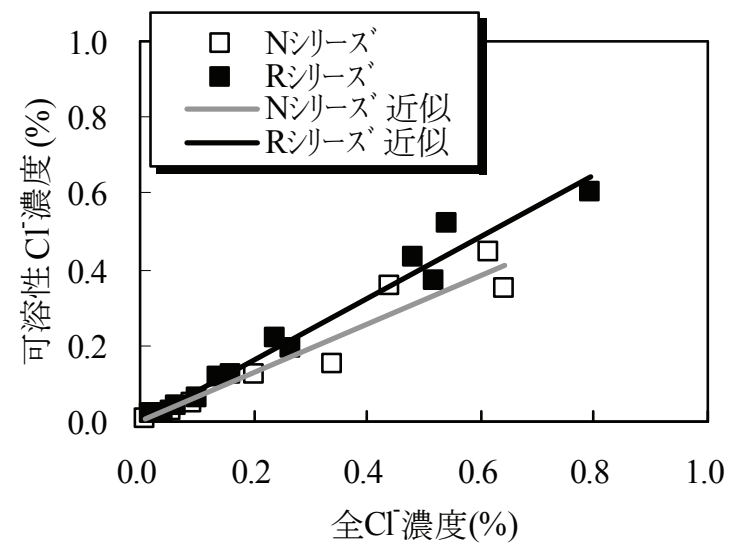

図-14 全塩化物イオン濃度と可溶性 塩化物イオン濃度の関係 


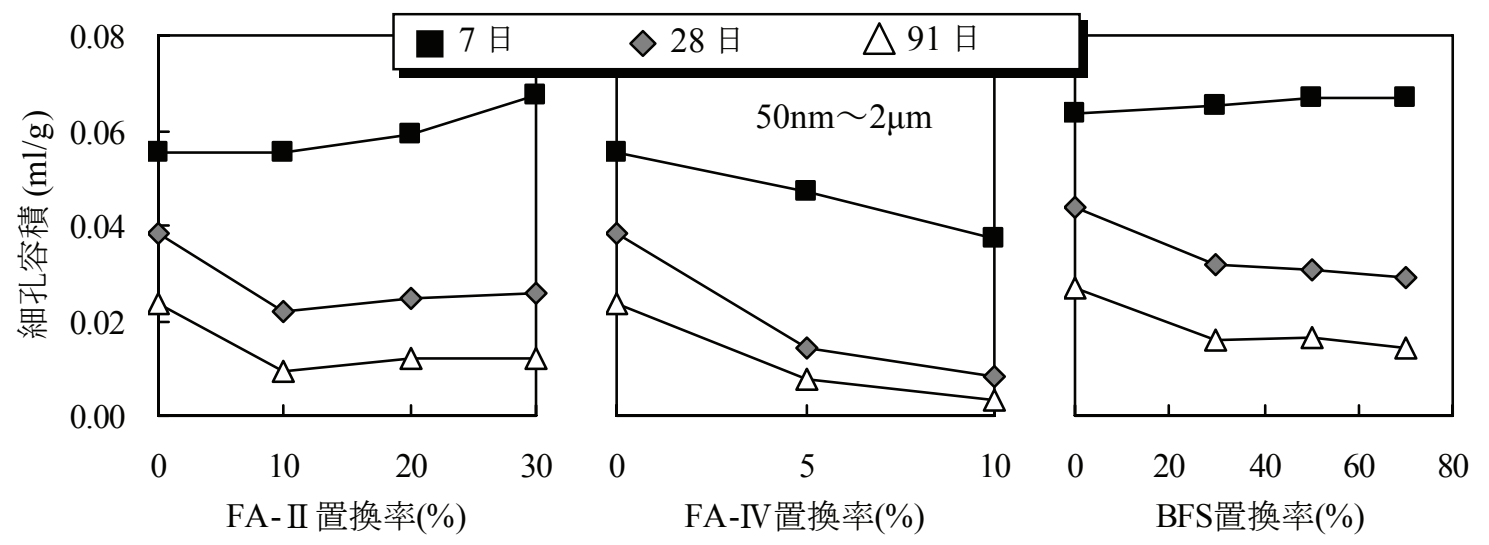

図-15 各種混和材置換率と細孔容積の関係 (再生モルタル)

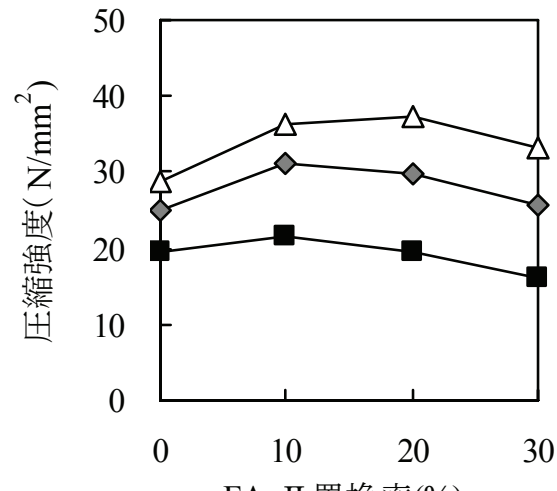

FA- II 置換率(\%)

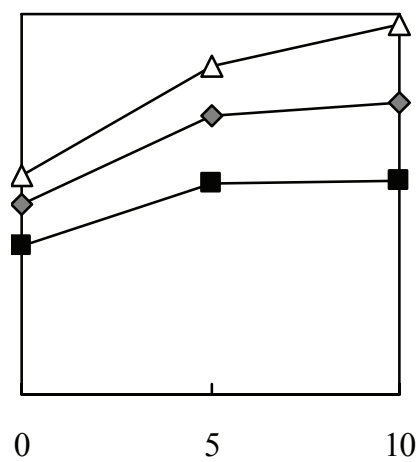

FA-IV 置換率 $(\%)$

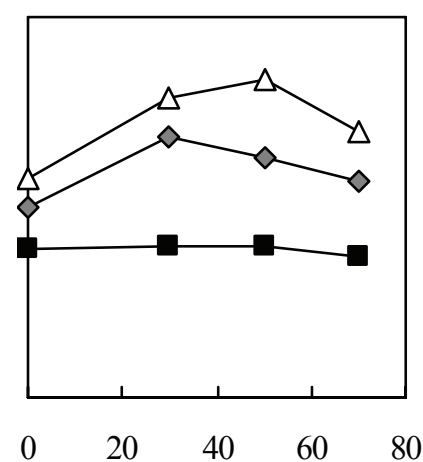

BFS置換率 $(\%)$

図-16 各種混和材置換率と圧縮強度の関係 (再生モルタル)

\section{(1) 混和材混入による細孔構造の変化}

図-15に再生モルタルにおける各種混和材置換率 と細孔容積の関係を示す. FA-II及びBFSを混入した 再生モルタル中のペースト部の細孔容積は初期材齢 においては無混和と同等もしくは大きいが長期材齢 になるに従い，緻密化していることが分かる．これ は，フライアッシュのポゾラン反応や高炉スラグの 潜在水硬性によるものであり, 再生モルタルにおい ても一般的な知見と一致する。また，FA-IVについ ては, 細骨材代替で混入していることから, 初期材 齢からの緻密化が確認され, 長期的にも大幅な細孔 構造の粗大化が改善されている.

以上のことから, 各種混和材を混入することによ り長期的な再生モルタルの細孔構造の緻密化が期待 できるといえる.

\section{（2）混和材を混入した再生モルタルの強度}

図-16に各種混和材置換率と圧縮強度の関係を示 す. 圧縮強度は細孔構造に依存するため, FA-IIや BFSのように初期材齢において細孔容積が大きいも のは強度が改善されていない。しかし, 長期材齢に おいては強度の改善が確認された。また，長期材齢 においてFA-IIでは置換率20\%, BFSでは置換率50\%

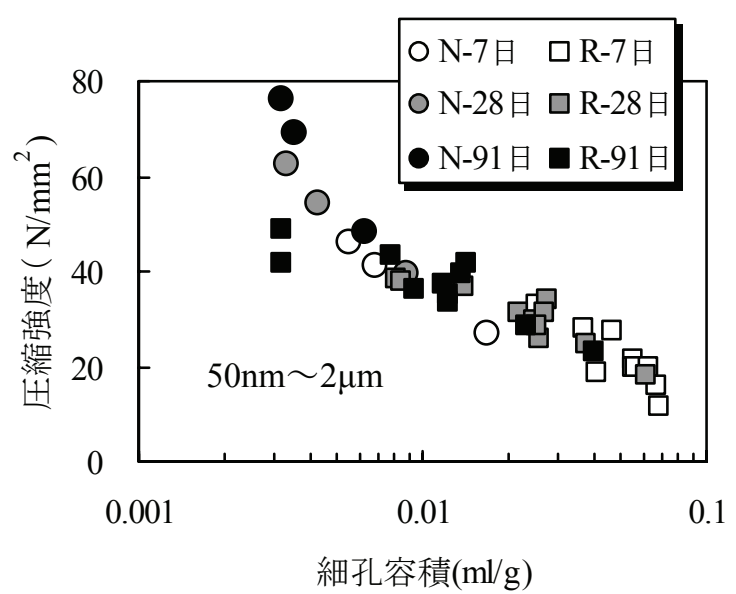

図-17 細孔容積と圧縮強度の関係

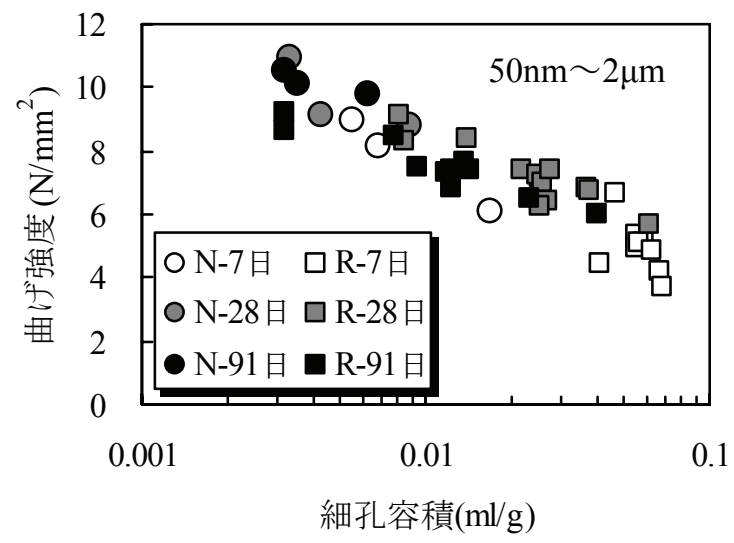

図-18 細孔容積と曲げ強度の関係 
が最も強度を改善する最適置換率であった。FA-IV を混入した再生モルタルの強度は, 初期材齢からの 細孔構造の緻密化により改善されており, 置換率の 増加に伴い大きくなった。

上述したように圧縮強度は細孔構造に依存するこ とから, 混和材を混入した再生モルタル中のペース 卜部の細孔容積と圧縮強度の関係について検討した。 図-17に各モルタルの細孔容積と圧縮強度の関係を 示す．なお，図中には図-7で示した水セメント比の 異なる標準モルタル及び再生モルタルのデータを併 記している. 図より, 骨材の種類及び混和材の有無, 水セメント比の違いに関わらず細孔容積の対数と圧 縮強度には相関関係が確認された。また, 図-18は 各モルタルの細孔容積と曲げ強度の関係を示してい る。図より，多少ばらつきがあるものの曲げ強度も 圧縮強度と同様に細孔容積に依存することが確認さ れた。

また，図一7においても述べたように再生モルタル の圧縮強度は細孔容積が減少しても強度の伸びが頭 打ちになっていることが分かる.これは, セメント マトリックスと骨材自身の強度の関係であると考え られる. 本研究で使用した再生骨材の $50 \mathrm{~nm} \sim 2 \mu \mathrm{m}$ に 存在する細孔容積は約 $0.016 \mathrm{ml} / \mathrm{g}$ であり, 再生モルタ ルの圧縮強度はこの值をしきい值として頭打ちにな るものと考えられる. 寸なわち, セメントマトリッ クスが骨材よりも細孔容積が多く, 弱い状態である 場合はセメントペースト部の遷移帯を起点とした破 壞形態となり，セメントマトリックスが骨材よりも 細孔容積が小さく, 強くなった場合は再生骨材自身 の脆弱部が起点となった破壊形態となるものと考え られる。

図-19にセメントペーストと骨材の細孔容積の関 係によるモルタルの破壊機構の違いの概念図を示す. 普通骨材を用いた場合, 高強度領域まで $W / C$ を低下 させると，セメントマトリックスが非常に強いため, 圧縮強度は頭打ちとなり, 骨材の強度に依存するこ
とが知られている ${ }^{22)}$. 再生骨材を用いた場合, この 現象が比較的高い $W / C$ でも生じるものと考えられる. また, 人工軽量骨材を用いた場合, 川砂利等と比較 して小さい $C / W て ゙$ 頭打ちとなることが確認されてい $る^{24)}$. 大即ら ${ }^{10}$ はビッカース硬さにより再生コンク リート中の境界相を把握し, 付着モルタルのビッカ 一ス硬さが新たなモルタル部のビッカース硬さより 大きい場合, コンクリートの強度は骨材の種類や品 質の影響を受けず, 新境界相のビッカース硬さに依 存すると報告している．以上のことから，再生骨材 を使用した場合, 圧縮強度の頭打ちとなるしきい值 は再生骨材自身の細孔容積によって定まり, セメン トマトリックスの細孔容積がそれ以下となると圧縮 強度に大きな伸びは見られないものと考えられる。 また，曲げ強度についてはそのような傾向が見られ ない. 曲げ強度に関しては, 骨材界面の付着性状が 問題となり, 再生骨材自身の細孔容積は大きく関与 していないものと考えられる. 今後, 多種の骨材を 使用し, それらの細孔容積と圧縮強度の関係を検討 することにより，この現象の解明が可能となるもの と考えられる.

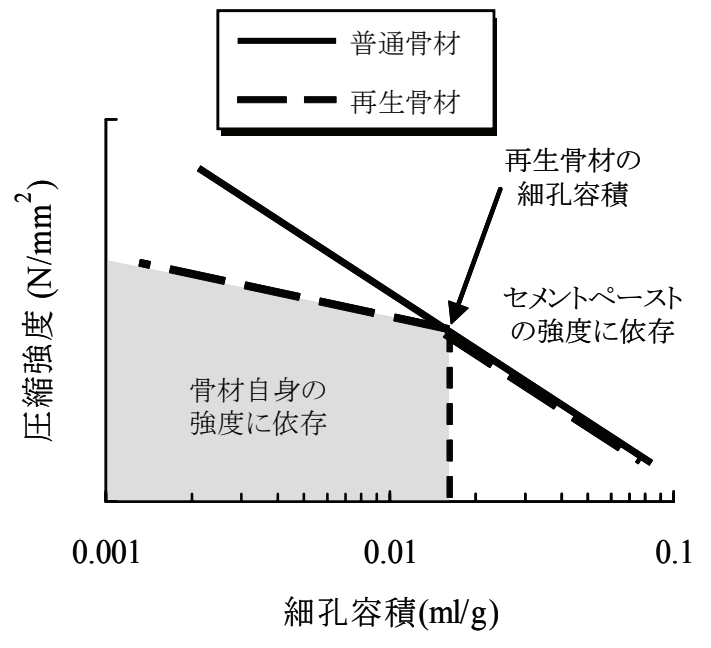

図-19 セメントペースト中の細孔容積により 生じる破壊形態の違いの概念図

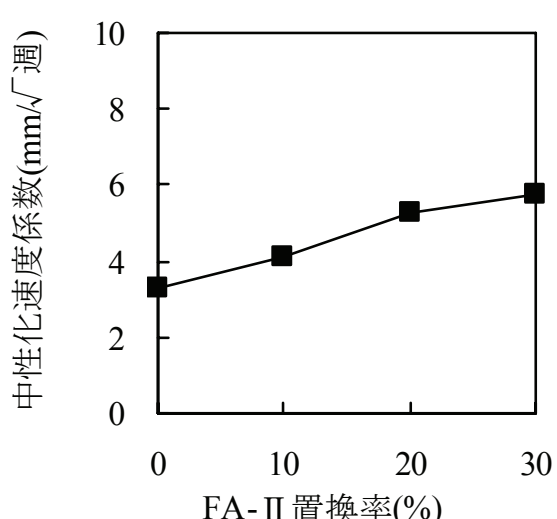

FA- II 置換率 $(\%)$

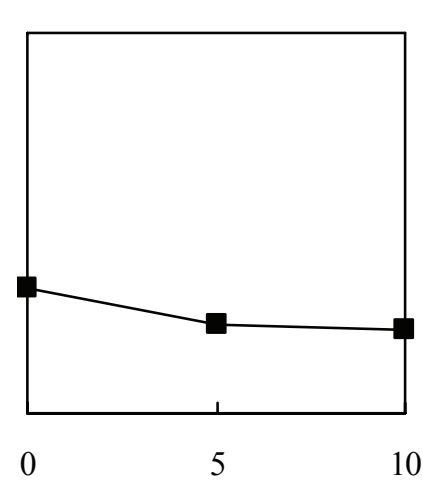

FA-IV 置換率(\%)

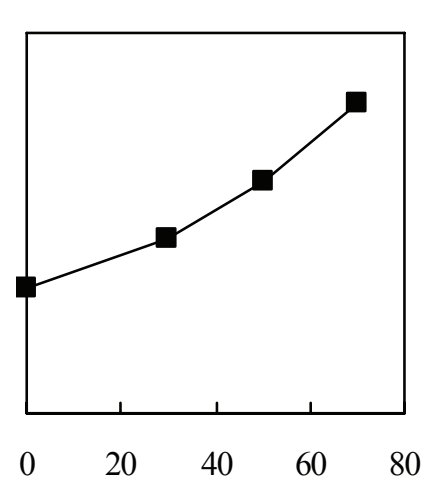

BFS 置換率( $\%)$

図-20 各種混和材の置換率と中性化速度係数の関係 (再生モルタル) 
（3）混和材を混入した再生モルタルの中性化性状

図-20に各種混和材置換率と中性化速度係数の関 係を示す．FA-II及びBFSを混入した再生モルタルは 単位セメント量が減少するため, 中性化速度が速く なることが分かる．特にFA-IIについては，フライ アッシュのポゾラン反応に伴う $\mathrm{Ca}(\mathrm{OH})_{2}$ 消費による 自己中性化 ${ }^{25}$ であると考えられる。また，FA-IVを 混入したモルタルについては, 中性化速度係数が多 少小さくなったものの，無混和のモルタルとほぼ同 等である。この理由として, 再生モルタルの細孔構 造が非常に粗大であるため，フライアッシュのポゾ ラン反応による緻密化よりも反応そのものに起因し て生じる自己中性化の影響を受け，中性化抵抗性が 十分には発揮できなかったものと考えられる.

ここで, 本研究は土木学会標準示方書[施工編]に 示される有効水結合材比 $W / B^{26)}$ 参考に，実用的に 評価が行い易い，細骨材の吸水率を考慮した有効総 水結合材比という概念を導入し，各種混和材を混入 した再生モルタルの中性化速度の評価を行った。有 効総水結合材比 $T W / B$ は以下の式(2)により表される.

$$
T W / B=\frac{W+W_{s}}{C_{p}+k \cdot A d}
$$

ここに,

$T W$ :単位体積あたりの総水量 $\left(\mathrm{kg} / \mathrm{m}^{3}\right)$

$W$ :単位体積あたりの水の質量 $\left(\mathrm{kg} / \mathrm{m}^{3}\right)$

$W_{s}$ : 単位体積あたりの細骨材の吸水量 $\left(\mathrm{kg} / \mathrm{m}^{3}\right)$ $C_{p}$ :単位体積あたりのセメントの質量 $\left(\mathrm{kg} / \mathrm{m}^{3}\right)$ $A d$ :単位体積あたりの混和材の質量 $\left(\mathrm{kg} / \mathrm{m}^{3}\right)$

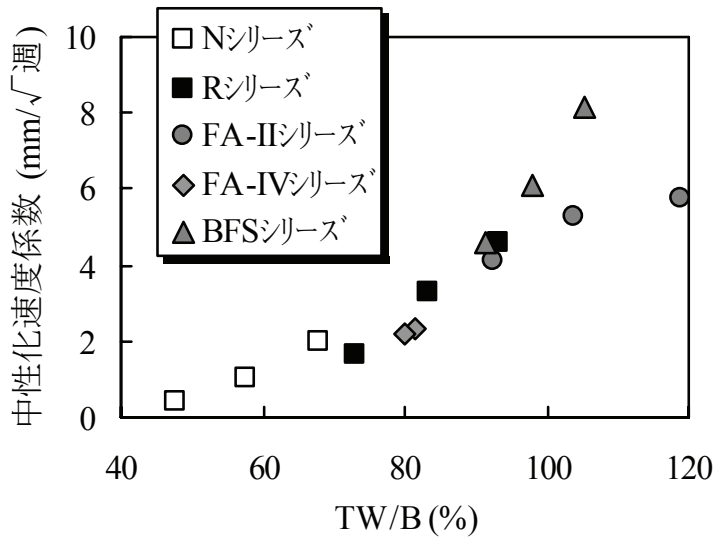

図-21 $T W / B$ と中性化速度係数の関係

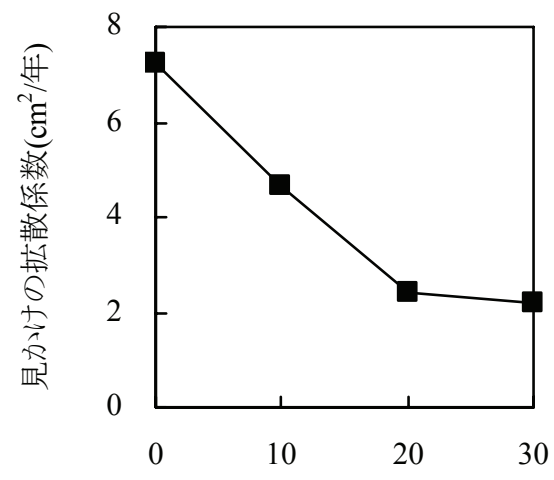

FA- II 置換率 $(\%)$

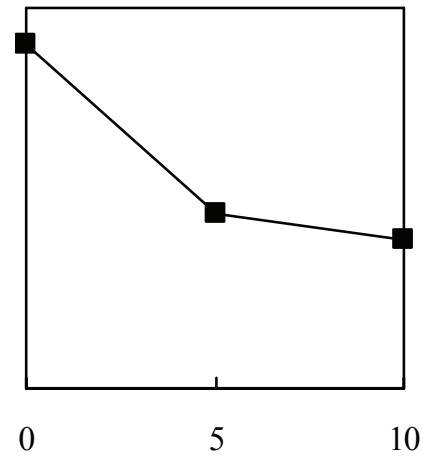

FA-IV 置換率 $(\%)$

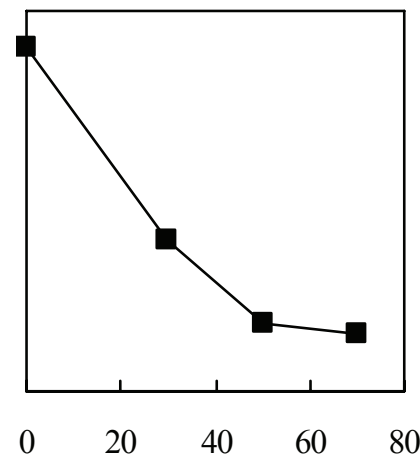

BFS置換率 $(\%)$

図-22 各種混和材置換率と見かけの拡散係数の関係

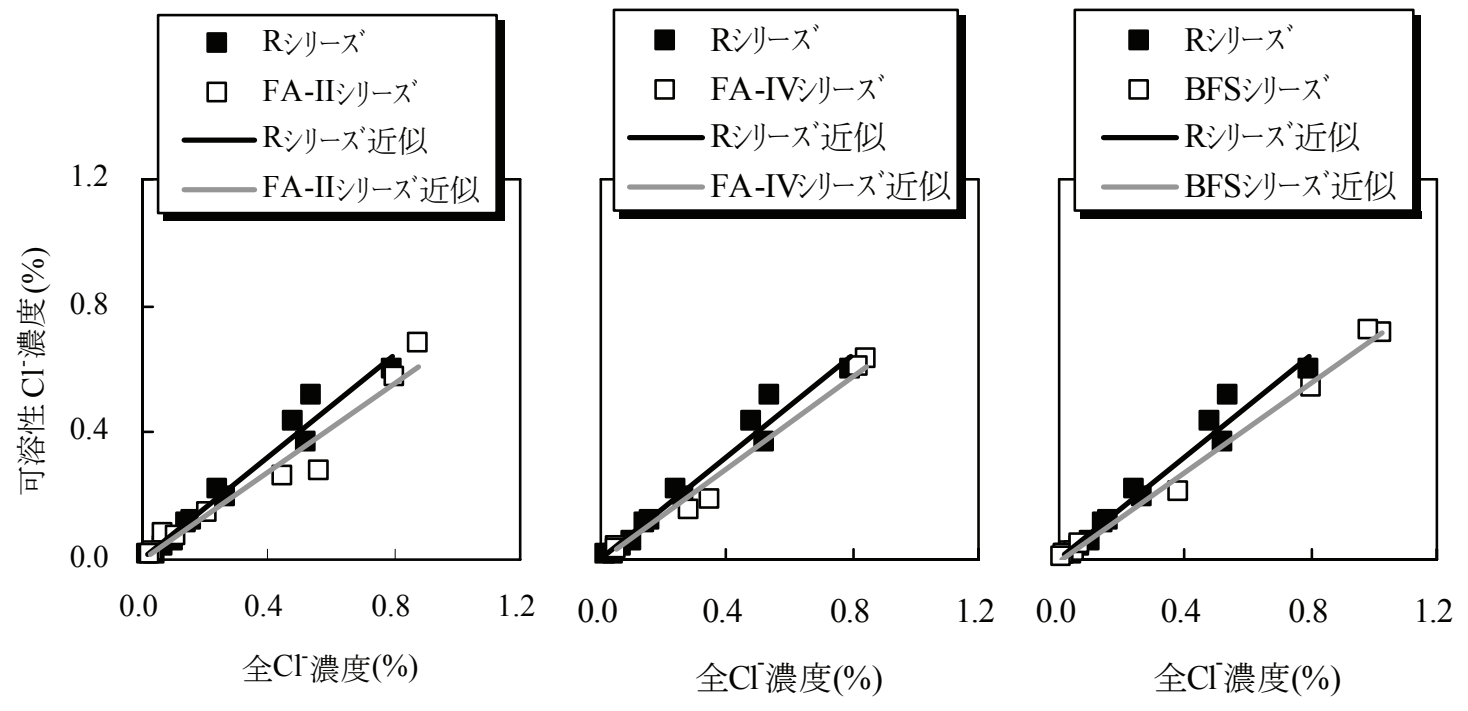

図-23 各種混和材を置換した再生モルタルの全塩化物イオン濃度と可溶性塩化物イオン濃度の関係 
$k$ : 混和材の種類によって定まる定数

フライアッシュの場合: $k=0$

高炉スラグ微粉末の場合: $k=0.7$

$B$ とは単位混和材量に係数 $k$ を乗じたものに単位 セメント量を加えた值であり，混和材の違いが中性 化性状に与える影響を考慮するものである。混和材 の中性化性状に与える影響は混和材の品質にも影響 されるが，土木学会標準示方書ではフライアッシュ について $k=0$, 高炉スラグ微粉末について $k=0.7$ を 採用しており，本研究においてもその值を採用する こととした.

有効総水結合材比 $T W / B$ と中性化速度係数の関係 を図-21に示す。図より，有効総水結合材比 $T W / B$ という概念を導入することにより再生モルタルと標 準モルタルを一義的に評価できる可能性が示唆され た。また，混和材の種類を考慮することにより混和 材を混入した場合のモルタルについても中性化速度 係数の算定がある程度予測可能であり，今後，多様 な骨材や混和材を用いることにより予測式を確立で きるものと考えられる。

以上のことから，再生骨材を使用したモルタルに おいて混和材による中性化抵抗性の改善は期待でき ないが， $T W / B$ という概念を導入することによって 混和材を混入したモルタルの中性化速度係数をある 程度予測可能であると言える。

\section{（4）混和材を混入した再生モルタルの塩分浸透性状}

図-22に試験材齢 13 週における各種混和材の置換 率と再生モルタルの塩化物イオンの見かけの拡散係 数を示す. 各種混和材の置換率の増加に伴い, 塩化 物イオンの見かけの拡散係数が大幅に小さくなって いることが分かる、特に, BFSを混入した再生モル タルの塩分浸透抵抗性の改善が顕著であった。

また，図-23は各種混和材を混入した再生モルタ ルにおける全塩化物イオン濃度と可溶性塩化物イオ ン濃度の関係を示している。混和材を混入した場合, 全塩化物イオン濃度に対する可溶性塩化物イオン濃 度の割合が小さくなっていることが分かる。この理 由として, 混和材の混入による塩化物イオンの固定 化と細孔構造の緻密化の2点が考えられる.

まず，固定塩化物イオン濃度を全塩化物イオン濃 度から可溶性塩化物イオン濃度を差し引いたものと 仮定すると，この近似直線の傾きの小さいもの程， 固定化割合が高いと解釈できる. フライアッシュ及 び高炬スラグ微粉末を混入したモルタルの固定化割 合は無混和の再生モルタルより高く, 混和材を混入 することにより全塩化物イオン濃度に対する可溶性

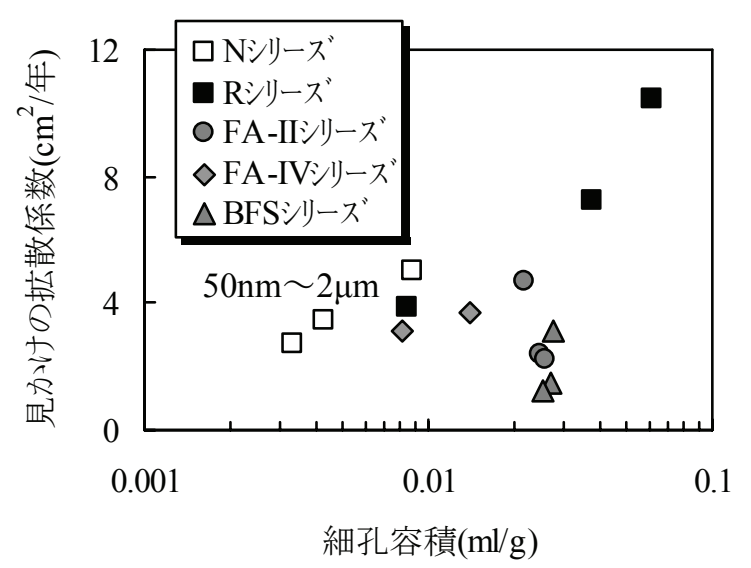

図-24 細孔容積と見かけの拡散係数の関係

塩化物イオン濃度を低下させることが出来る。しか し，混和材を混入した再生モルタルと無混和の再生 モルタルの近似直線の傾きの差は小さなものであり, 混和材による固定化能のみが再生モルタルの塩分浸 透抑制効果に大きく関わっているとは言い難い.

次に, 混和材混入による細孔構造の緻密化によっ てモルタル中の固相に対する液相の割合が減少し, 全塩化物イオン濃度に対する可溶性塩化物イオン濃 度の割合が低下することが考えられる。図-24は各 種混和材を混入した再生モルタルの $50 \mathrm{~nm} \sim 2 \mu \mathrm{m}$ の細 孔容積と塩化物イオンの拡散係数の関係を図-13に 加筆したものである。混和材を混入した再生モルタ ルは細孔容積が標準モルタルよりも大きいが，見か けの拡散係数は小さいことが分かる. 寸なわち, 混 和材を混入した再生モルタルにおいても固相に対す る液相の割合が標準モルタルと比較して大きいにも 関わらず，塩分浸透抑制効果を十分に発揮している。 これらのことから，フライアッシュ及び高炉スラ グ微粉末混入による塩分浸透抑制機構は混和材によ る塩化物イオンの固定化能や細孔構造の緻密化以外 に細孔表面の電位の変化 ${ }^{27}$ 等の諸要因を加味する必 要があると考えられるが，混和材を混入することに より再生モルタルの塩分浸透抵抗性を大幅に改善す ることが可能であることが明らかとなった。

\section{6. 再生モルタルの強度・耐久性改善のための 最適な各種混和材の置換率}

これまでの結果より，混和材を混入することによ って強度及び耐久性を改善する上で一長一短がある ことが確認された。再生骨材を使用する上で，施工 上の観点からプレウェッティングを行う必要がある 
ため, 低品質な再生骨材を用いた場合は強度低下が 免れない, 再生モルタルの強度改善として, 各種混 和材の混入は低コストで行うことの出来る方法であ ると言える。

本研究の範囲において, FA-IIをセメント質量に 対して内割で混入する場合, 強度を改善するために は置換率 $20 \%$ が最適であるが, 中性化抵抗性が低下 する．FA-IVを細骨材体積置換により混入する場合， 中性化抵抗性はほぼ同等で強度は改善出来るが,

FA-IIやBFS程の十分な塩分浸透抵抗性が得られない. さらに，BFSをセメント質量に対して内割で混入す る場合, 強度に関しては置換率 $50 \%$ が最適であり, 置換率 $30 \%$ 以上で十分な塩分浸透抵抗性の確保が可 能であるが，中性化抵抗性が大幅に低下する．今後， 各種混和材の適切な置換率を設定するためには多種 多様な骨材や品質の異なる混和材を使用した実験を 行う必要がある。

また，現在は再生骨材に関してASR反応性を判定 する試験方法が確立されていない。 また, 原コンク リートに使用した骨材の試験成績書があるとは限ら ない，そのため，再生骨材を使用するためにはフラ イアッシュセメントB種及び高炉セメントB種等の 混合セメントの使用やフライアッシュの細骨材補充 混和材としての混入が必要不可久である. 例えば, セメントに内割で混和材を混入する場合, 最低限と してフライアッシュ混入率 $15 \%$ 程度, 高炉スラグ微 粉末 $40 \%$ 程度の混入率が必要である.

以上のことから，再生骨材を使用する上で混和材 を混入することにより強度や塩分浸透抵抗性, ASR 抑制対策を行い, 中性化については本研究が提案し た有効総水結合材比 $T W / B$ で予測することが望まし いであろう。

\section{7. 結論}

本研究は表乾状態で再生骨材を使用したモルタル における強度及び而久性の低下機構について考察し, その改善方法について検討した。 以下に, 本研究か ら得られた知見を示す. なお, 本研究は 1 種類の再 生骨材を用いた結果であり, 今後のデータの蓄積が 必要である。

(1)再生骨材を使用したモルタルは新セメントペース 卜部の細孔構造がポーラスになり, 強度及び耐久 性が低下寸る。これは再生骨材から水分が渗出す ることによるものと推察される。また, 再生骨材
を使用したモルタルの強度や中性化速度係数及び 塩化物イオンの見かけの拡散係数は再生モルタル 中の新ペースト部に存在する $50 \mathrm{~nm} \sim 2 \mu \mathrm{m}$ の細孔容 積と高い相関がある。

(2)再生骨材を使用したモルタルは, 各種混和材を混 入することにより強度がある程度改善可能である。 これは, 混和材の混入に伴う緻密化によるもので あると考えられる. 塩分浸透抵抗性は, 混和材の 混入により大幅な改善が可能である. この原因に ついては明確になっていない, また, 中性化抵抗 性は混和材の混入により低下寸る。これは, セメ ント量の減少によるものであると推察される.

(3)各種混和材混入の有無に関わらず, 再生骨材の影 響を受けない範囲においては，セメントペースト 部に存在する $50 \mathrm{~nm} \sim 2 \mu \mathrm{m}$ の細孔容積と強度には 相関関係がある。再生骨材自身の影響を受ける低 水結合材比では圧縮強度が頭打ちとなる可能性が ある.このしきい值については今後の検討課題で ある。

(4)骨材の種類及び混和材の種類や置換率を考慮した 有効総水結合材比 $T W / B$ によってモルタルの中性 化速度係数を一義的に評価できる可能性がある.

\section{参考文献}

1）島裕和, 鴻巣一巳, 橋本光一, 古賀康男: 加熱すり もみ法によるコンクリート塊からの高品質骨材回収 技術の開発，コンクリート工学年次論文集，Vol.22， No.2, pp.1093-1098, 2000

2) 立屋敷久志, 岡本雅道, 西村祐介, 黒田泰弘 : 解体 コンクリートからの高品質再生骨材の回収試験, コ ンクリート工学年次論文集, Vol.22, No.2, pp.10991104, 2000

3）高橋智彦, 大久保嘉雄, 長瀧重義 : 重回帰分析等を 用いた再生コンクリートの強度特性に関する評価, コンクリート工学年次論文集, Vol.24, No.1, pp.1227-1232, 2002

4）松下博通, 鶴田浩章, 佐川康貴, 若林幹夫 : 再生コ ンクリートの耐久性に関する検討, セメント・コン クリート論文集，No.57，pp.541-547，2003

5）松下博通, 鶴田浩章, 陶佳宏, 久保野敦: 再生骨材 コンクリートの強度および乾燥収縮特性に関する一 考察，セメント・コンクリート論文集，No.54，2000

6) 柴田辰正, 岡本享久, 河野広隆, 加藤俊二 : 収縮低 減剤が再生骨材コンクリートの品質改善に及ぼす影 響, 第 50 回セメント技術大会講演要旨, pp.348-349, 1996

7）鶴田浩章, 松下博通, 陶佳宏, 近田孝夫 : 品質の異 なる再生骨材を使用したコンクリートの強度性状, コンクリート工学年次論文集, Vol.24, No.1, pp.1317-1322, 2002

8）麓隆行, 山田優 : 再生細骨材の使用がコンクリート の性状に及ぼす影響とその原因について, 土木学会 論文集，No.767/V-64，pp.61-73，2004.8 
9）長瀧重義, 佐伯竜彦, 飯田一彦 : 再生粗骨材を用い たコンクリートの諸特性, セメント・コンクリート 論文集，No.52，pp.444-449，1998

10）大即信明, 宮里心一, 原法生, Yodsudjai Wanchai： 再生骨材コンクリートの物質透過性および強度の評 価とその結果に基づく改善方法の提案，コンクリー 卜工学論文集, Vol.12, No.2, pp.1-12, 2001

11 ) Poon, C.S., Shui, Z.H. and Lam, L. : Effect of microstructure of ITZ on compressive strength of concrete prepared with recycled aggregates, Construction and Building Materials, Vol.18, pp.461-468, 2004

12）佐川康貴, 松下博通, 川端雄一郎：再生コンクリー トの中性化及び塩分浸透に関する研究，コンクリー 卜工学年次論文集, コンクリート工学年次論文集, Vol.27, No.1, pp.1345-1350, 2005

13）中本純次, 戸川一夫, 三岩敬孝, 吉兼亨 : 再生骨材 の品質がコンクリートの諸特性に及ぼす影響, コン クリート工学年次論文集, Vol.20, No.2, pp.11291134, 1998

14）宮本高秀, 湯浅幸久, 犬飼利嗣, 畑中重光 : シリカ フュームによる再生骨材の品質改善の可能性に関す る研究, セメント・コンクリート論文集, No.55, pp.688-693, 2001

15）辻正哲, 笹倉伸晃, 澤本武博, 奥山厚志 : コロイダ ルシリカを用いた再生骨材コンクリート強度の改善 方法に関する研究, 土木学会第 55 回年次学術講演概 要集 V, pp.396-397, 2001

16）黑田泰弘, 橋田浩, 山崎庸行, 立屋敷久志 : 高品質 再生骨材を使用したコンクリートの基本性状，コン クリート工学年次論文集, Vol.22, No.2，2000

17）今本啓一, 大橋潤一, 西尾篤志, 田村博 : 減圧工法 による再生骨材コンクリートの品質向上，コンクリ 一下工学年次論文集, Vol.21, No.1, pp.175-180, 1999
18）内川浩, 羽原俊祐, 沢木大介：硬化モルタル及びコ ンクリート中の遷移帯厚さの評価並びに遷移帯厚さ と強度との関係の検討, コンクリート工学論文集, Vol.4, pp.1-8, 1993

19) Zimbelmann, R. : A Contribution to The Problem of Cement-Aggregate Bond, Cement and Concrete Research, Vol.15, pp.801-808, 1985

20）加藤佳孝，魚本健人：遷移帯の特性に着目した硬化 体の物質移動特性のモデル化, 土木学会論文集, No.655/V-48, pp.13-21，2000

21）田中秀治, 古賀裕久, 河野広隆 : 高炉スラグ微粉末 を含むセメント硬化体中の可溶性塩分量の測定に関 する検討, 土木学会第 59 回年次学術講演会概要集 V, pp.271-272, 2004.9

22）村田二郎：人工軽量骨材コンクリート，コンクリー トパンフレット, セメント協会, pp.47-55, 1967

23）羽原俊祐：硬化コンクリートの組織及び空隙構造と 物性の関係に関する研究, 慶応大学学位論文, p.150, 1992

24）國府勝郎, 飛坂基夫 : 高強度コンクリートと骨材, コンクリート工学, Vol.28, No.2, pp.14-22, 1990.2

25）黄光律, 野口貴文, 羽原俊祐, 友澤史紀 : フライア ッシュを外割混合したモルタルの中性化特性, コン クリート工学年次論文集, Vol.21, No.2, pp.109-114, 1999

26）土木学会 : 2002 年制定コンクリート標準示方書【施 工編】, p.79, 2002

27）吉田行, 田口史雄, 名和豊春, 渡辺宏 : 高炉スラグ 微粉末を用いたビーライト系セメントコンクリート の塩分浸透に及ぼす諸要因の影響, コンクリート工 学年次論文集, Vol.26, No.1, pp.777-782, 2004

(2005. 5. 26 受付)

\title{
THE EFFECT OF MICROSTRUCTURE ON STRENGTH AND DURABILITY OF MORTAR INCORPORATING RECYCLED FINE AGGREGATE
}

\author{
Hiromichi MATSUSHITA, Yasutaka SAGAWA and Yuichiro KAWABATA
}

This study reports the decrease of strength and deterioration mechanism of mortar incorporationg recycled fine aggregate from the viewpoint of porosity. Pore volume of cement composites with recycled aggregate was large. Thus, strength of mortar incorporationg recycled aggregate decreased. Pore volume of $50 \mathrm{~nm} \sim 2 \mu \mathrm{m}$ affected strength, carbonation speed and diffusion coefficient of chloride ion.

In order to improve the strength and durability of recycled mortar, in this study mineral admixtures such as ground granulated blast-furnace slag and fly ash were used. Strength and diffusion coefficient of chloride ion of mortar were improved, but carbonation speed was larger than that of normal mortar. Carbonation speed was evaluated by total water-effective binder ratio. 